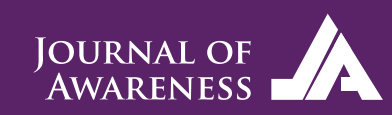

$\left(\begin{array}{l}0 \\ 0\end{array}\right)$

\title{
Zeytin çekirdeği külünün artistik seramik sırlarında kullanımı*
}

Usage olive seed ash in artistic ceramic glazes

\section{Gülşah Divitcioğlu ${ }^{1}$ (D) Mehmet Fatih Karagül ${ }^{2}$}

1 Öğrenci, Çanakkale Onsekiz Mart Üniversitesi, Sosyal Bilimler Entitisü (Mezun), Seramik ASD, Çanakkale, TÜRKIYE, e-mail: zeynepgulsah0@gmail.com 2 Prof. Dr., Çanakkale Onsekiz Mart Üniversitesi, Güzel Sanatlar Fakültesi, Seramik ve Cam Bölümü, Çanakkale, TÜRKIYE, e, mail: fkaragul@comu.edu.tr

\section{Öz}

Çanakkale'de Olea europea oleaster ve Olea europea sativa olmak üzere iki tür zeytin yetişmektedir. Çanakkale'de ilk zeytincilik faaliyetleri Ayvacık ilçesindeki Küçükkuyu'da yer alan antik Gargara kentinde gerçekleşmiştir. Böylelikle Çanakkale için zeytin tarımının MÖ 6. yy. a tarihlendirilebileceğini önerebiliriz. Özellikle Akdeniz havzasında yetiştirilen zeytin antik çağlardaki çok tanrılı dinlerde ve rahmani dinlerde önemli bir yere sahiptir. Zeytin insanlık tarihi boyunca kullanılabilirlik özellikleri nedeniyle çok eski dönemlerden itibaren zirai bir ürün olarak hayatımızın vazgeçilmez parçalarından birisi olmuştur. Bu nedenle makalenin ana konusunu zeytin çekirdeğinden üretilen kül sırları oluşturmaktadır ve seramik üretiminde kullanılan artistik sırlar arasında değerlendirilirler. Bu küllerin elde edilmesinde organik olan herhangi bir hammaddenin yanmış olan külleri kullanılabilir. Yaşadığımız Çanakkale coğrafyası ile bağ kurup, yerel bir değer olan zeytine önem çekmek adına daha önce çalışılmamış olan zeytin çekirdeği külü araştırmamızı gerçekleştirme noktasında teşvik edici olmuştur. Antik Troas bölgesinde yer alarak efsanelere kaynaklık eden ve mitolojide Troia gibi bir değeri bünyesinde taşıyan Çanakkale genelinde yaygın olan zeytin ve zeytinden elde edilen kül, seramik sırlarıyla bağlantılı yerel bir değer olması nedeniyle özellikle seçilmiştir.

Anahtar kelimeler: seramik, artistik, kül sırı, zeytin külü

"Bu makale Çanakkale Onsekiz Mart Üniversitesi Sosyal Bilimler Enstitüsü Seramik A.S.D. da Gülşah Aksoy tarafından 10.06.2019 tarihinde hazırlanan ve 25.06.2019 tarihinde enstitü müdürlüğünce onaylanan “Anadolu'da Artemis Kültü Ve Seramik Sanatına Yansıması” adlı tezden türetilmiştir. 


\begin{abstract}
Two types of olives, Olea europea oleaster and Olea europea sativa, are grown in Çanakkale. The first olive growing activities in Çanakkale took place in the ancient Gargara city in Küçükkuyu in Ayvacık district. Thus, olive farming for Çanakkale in the 6 th century BC We can suggest that it can be dated to a. Olives, especially grown in the Mediterranean basin, have an important place in polytheistic and celestial religions in ancient times. Olive has been one of the indispensable parts of our lives as an agricultural product since ancient times due to its usability features throughout human history. For this reason, the main subject of the article is ash glazes produced from olive pits and they are considered among the artistic glazes used in ceramic production. Burnt ashes of any organic raw material can be used to obtain these ashes. It has been an incentive for us to carry out our research on olive ash ash, which has not been studied before, in order to connect with the geography of Çanakkale where we live and to draw attention to the local value of olive. Olive and olive ash, which is common in Çanakkale, which is located in the ancient Troas region and is the source of legends and carries a value like Troia in mythology, was especially chosen because it is a local value associated with ceramic glazes.
\end{abstract}

Keywords: ceramic, artistic, ash glaze, olive ash

\section{GİRIŞ}

Zeytin insanlık tarihi boyunca kullanılabilirlik özellikleri nedeniyle çok eski dönemlerden itibaren zirai bir ürün olarak hayatımızın vazgeçilmez parçalarından birisi olmuştur. Sağlık yönünden çok önemli bir hammadde kaynağı olan zeytinin bu yönü makale konusu dışında tutulmuş, özellikle antik çağlardan günümüze seramik üretiminde doğrudan ya da dolaylı olarak zeytinin kullanımına değinilmiştir. Makalenin ana konusunu ise zeytin çekirdeğinden üretilen kül sırları oluşturmaktadır.

Kül sırları seramik üretiminde sanatsal ve görsel zenginlikler sunan artistik sırlar arasında değerlendirilirler. Bu küllerin elde edilmesinde organik olan herhangi bir hammaddenin yanmış olan külleri kullanılabilir. Konu ile ilgili yurdumuzda yapılmış olan çalışmalar incelendiğinde, kayın, akasya, meşe, asma, elma, gürgen, kavak, kiraz, zeytin ve ceviz ağaçlarının küllerinin kullanıldığ1 (Güneş, 2014: 95-143), çam ağacı (Güneş, 2014: 95-143, Alkan, 1998: 5), patlıcan dalı (Tizgöl, ve diğ. 2016: 11-20), ceviz kabuğu ve soya fasulyesi (Alkan, 1998: 6-7), gül posası (Ünal ve diğ., 2020, 90-104), kestane kabuğu (Kubat, 2020: 61-70), patates kabuğu (Şölenay ve diğ., 2020: 61-70), şeker pancarı küspesi (Sarnıç vd diğ., 2007: 1100-1106) gibi doğal atıkların, geri dönüşümle kül sırlarının üretiminde kullanılabildiği görülmüştür. Yurt dışında gerçekleştirilen paralel çalışmalar incelendiğinde ise kullanılan küllerin kendi aralarında karıştırılarak farklı terkipler oluşturduğu da tespit edilmiştir. Kimi zaman da yabancı yayınlardaki sır reçetelerinde yalnızca küller olarak belirtilmişlerdir. Phil Rogers kitabında (2003:31,33,34,35,37) verdiği sır reçetelerinde kül, odun külü, karışık kül, tabirlerini kullanmanın yanı sıra, Soji Hamada'nın sır reçetesinde kullandığı çam külü ve Carol Metcalfe'nin sır reçetesinde kullandığı yıkanmış keten tohumu külüne de kitabında yer vermiştir $(2003: 25,29)$. Yaşadığımız Çanakkale coğrafyası ile bağ kurup, yerel bir değer olan zeytine önem çekmek adına daha önce çalışılmamış olan zeytin çekirdeği külü ise araştırmamızı gerçekleştirme noktasında teşvik edici olmuştur.

Özellikle Akdeniz havzasında ziraatı yapılan zeytin hem antik çağlardaki çok tanrılı dinlerde hem de rahmani dinlerde önemli bir yere sahiptir. Yunan mitolojisinde tanrıça Athena zeytini, antik Atina kentine hediye olarak vermiştir (Hepoğlu ve diğ., 2019: 4-6). M.S. 4-70 yılları arasında yaşayan Romalı yazar Columella zeytin ağacını ağaçların atası olarak değerlendirip, ilk kutsal ağaç olarak belirtmiştir (Nahya 2011: 88, İplikçi ve diğ., 2018: 14, Gökçe ve diğ., 2020: 148). Tevrat'taki "Ama ben Tanrı'nın evinde yeşeren zeytin ağacı gibiyim, sonsuza dek Tanrı'nın sevgisine güvenirim" (Mezmurlar, 52:8) ifadesi, zeytin ile Tanrının bağını önemli bir biçimde ortaya koymaktadır. “... Eğer kök kutsalsa dallar da kutsaldır. Ama zeytin ağacının bazı dalları kesildiyse ve sen, yabani zeytin filizi olarak onların yerine aşılanıp, öz ağacın semiz köküne ortak oldunsa ortak oldunsa dallara karşı övünme. Eğer övünüyorsan unutma ki, sen kökü taşımıyorsun, kök seni taşıyor..." (Romalılara Mektup 11:16-24) İfadesi ile İncil'de zeytinin kutsiyeti üzerinde durulmuştur. Kur'an-1 Kerim'de ise zeytinden “Mübarek bir ağaçtan ne doğuya ne de batıya ait olan zeytin ağacından tutuşturulur. Bu ağacın yağı, ateş dokunmasa bile, nerdeyse aydınlatacak (kadar berrak) tır" (Nur Suresi 35. Ayet) şeklinde bahsedilerek, zeytinyağının önemi vurgulanmıştır. İslamiyet'te zeytin ağacı üzerine yemin edildiği 
de bilinmektedir (Gömeç, 2003: 88, Ateş, 2012: 59). Zeytin, Nuh tufaninın sonunda, hayatta kalan insanlara yeni bir başlangıç, müjde olarak gagasında zeytin dalı getiren kuş (güvercin) sembolizmi ile barışın evrensel simgesi olarak uluslararası anlamda sosyal hayatımızda yer etmiştir. Bu bağlamda zeytin ve seramik arasında bağ kuran kül sırlarında zeytin çekirdeğinin kullanımi, araştırma çalışmamızı gerçekleştirmede etken olan bir diğer nedendir.

\section{TROAS, ZEYTIN VE ARTEMIS}

İlyada'da konu edilen Troia savaşında, Troia'lıların müttefiki olan Artemis Anadolu'lu bir tanrıçadır. Artemis doğa ve hayvanların koruyucusu olarak bilinmesinin yanı sıra bitki âlemi ve şifa ile yakından ilgilenmiştir. Artemis'in bitki totemleri arasında zeytin bulunmaktadır. Antik Troas bölgesinde yer alarak efsanelere kaynaklık eden ve mitolojide Troia gibi bir değeri bünyesinde taşıyan Çanakkale genelinde yaygin olan zeytin ve zeytinden elde edilen kül, seramik sırlarıyla bağlantılı yerel bir değer olması nedeniyle özellikle seçilmiştir. Rivayete göre zeytin, Artemis'in en sevdiği ağaçlardan birisi olarak gösterilmektedir. Bunun nedeni ise zeytin yaprağının ay ışığı altındaki gümüşi rengidir. Zeytinin Artemis ile bağlantısının bir diğer nedeni Artemis'in doğum günü olarak kabul edilen mayıs ayında (Şahin, 2013:145) zeytin ağaçlarının güzel kokulu çiçeklerle bezeli olmasıdır (URL 1). Makale kapsamında oluşturulan heykellerin yeşil renk kül sırla sırlanmış olması ise zeytin ağaçlarını sembolize etmektedir.

Çanakkale'de Olea europea oleaster (delice) ve Olea europea sativa (ehli) olmak üzere iki zeytin türü yetişmektedir. Ilgar'ın belirttiğine göre Çanakkale'deki ilk zeytincilik faaliyetleri Ayvacık ilçesindeki Küçükkuyu'da yer alan antik Gargara kentinde gerçekleşmiştir (Ilgar, 2016:19). Yunan kolonizasyonu öncesi Ege kıy1larının Çanakkale topraklarına Anadolu halklarından Leleg'lerin yerleştikleri ve Gargara'da (Strabon 13: 56,58, 141-142) yaşadıkları bilinmektedir ve Cook'a göre Gargara kentinin MÖ 6. yy. a tarihlenen (Cook, 1973: 255-261) şehir duvarları ve tapınak temelleri kentin tarihi geçmişi hakkında net bilgi vermektedir. Böylelikle Çanakkale için zeytin tarımının MÖ 6. yy. a tarihlendirilebileceğini önerebiliriz.
Şekil 1. Boyunlu amfora

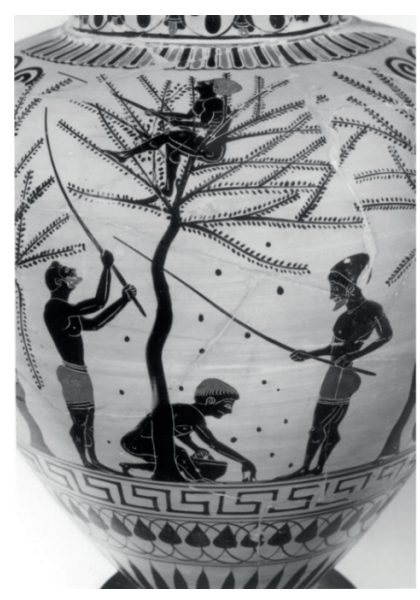

Kaynak: Londra, British Museum, B 226 (https://www.britishmuseum.org/collection/object/G_1837-0609-42)

Antik çağdaki zeytin tarımına ait görsel kanıtları, seramik yüzey bezemelerinde de görebilmekteyiz. M.Ö. 520-510 y1llarına tarihlenen ve Antimenes ressamı tarafından şekillendirilmiş olan boyunlu amforanın yüzeyinde yer alan siyah figür tekniğindeki grup figür, zeytin hasadı yapan iki erkek ve iki çocuğu betimlemektedir (Bkz: Şekil 1). Bu seramik betimlemesinden de anlaşıldığı kadarıyla, zeytin hasadında, makineleşme haricinde bir değişiklik olmamıștır. Yetișkin erkeklerin ellerindeki sopalarla zeytin tanelerini düşürdükleri, dökülen zeytinleri ve ağacın tepesindeki ulaşılması zor yerdeki zeytin tanelerini elle toplayan gençlerin faaliyetleri günümüzde de devam etmektedir.

Serdaroğlu'nun (1994) belirtmesine göre, antik çağda siyah figürlü seramiklerin pişirim sırasında uğradıkları redüksüyon süreciyle büründükleri etkili, parlak, göz alıcı siyah rengin (firnis), antik çömlekçilerin pişirim sırasında kullandıkları yaş zeytin dallarını, redüksiyonu gerçekleştirmek için fırının içine atmış olmalarından kaynaklanmaktadır. Bahsedilen zeytin dalının redüksiyonda kullanılması süreci, budanarak seyreltilen zeytinin dallarının Ege kıyılarında kolaylıkla temin edilebilir olması nedeniyle bağlantılıdır. Şekil 1 de görüldüğü üzere, zeytinin toplandığı ağaç betimlemesindeki dallar budanarak seyreltilmiştir. Ancak bu sayede, zeytin ağacından verim alınabilmektedir. Budanan dallar sayesinde antik çömlekçiler için kullanışlı bir yakacak elde edilmiş olmaktadır. Bu özel pişirim sayesinde, zeytinin seramikçiler için farklı bir yönden önemli bir malzeme olduğu göz ardı edilmemelidir. 
Toplumlara göre zeytin kimi zaman hayat ağaciyla (Ateş, 2012:19) özdeşleştirilerek sembolleştirilmiştir. $\mathrm{Bu}$ durum muhtemelen zeytinin sağlığa faydaları ile bağlantılı olmalıdır. Bu tema ise apayrı bir makale konusudur.

\section{KÜL SIRI VE ÖZELLİKLERİ}

Kül; organik, genellikle bitkisel maddelerin yanması neticesinde ortaya çıkan, artık yanmaz hale gelen maden tuzlarına verilen isimdir. Kül sırları ilk olarak Çin'de Shang hanedanlığı zamanında (M.Ö. 1500) tesadüf eseri ortaya çımış ve ilk kez Çinli seramik ustaları tarafından kullanmıştır. Seramik tarihinin en eski sırı olarak bilinen kül sırı, sıcaklığın yükselmesiyle birlikte odunlu fırınlarda uçuşan küllerin, seramik yüzeyine yapışması ve yüzey üzerinde bütünleşmesiyle oluşan camsı tabakaya denilmiştir. Sonraları laboratuar ortaminda hazırlanan odun külü veya herhangi bir bitkisel kökenli kül, kil ve feldspat birleştirilerek kül sırı oluşturulmuştur (Genç, 2013:126).

Kül sırı yapımında bitkisel kökenli çeşitli bitki küllerinden yararlanılır ve sır bünye içerisinde ergitici olarak kullanılmaktadır. Külü kullanılan bitkinin yapısına ve elde edilen külün içerisinde kullanıldığı sırın bileşimine ve pişirim sıcaklığına göre kül sırı farklı sır etkileri göstermektedir. Bütün bitkisel maddeler temelde hidrojen ve karbon bileşiklerinden oluşmaktadır. Ancak yakıldığında yanıcı olmayan ve temelde altı ana seramik oksit (alümina, silis, kalsiyum, sodyum, potasyum ve magnezyum) olan küçük bir yığın halini almaktadır. Bitki küllerinin kimyasal analizlerine bakıldığında, genel olarak \%10-15 Al2O3, \%30-70 SiO2, \%15'e kadar $\mathrm{Na} 2 \mathrm{O}$ ve K2O, \%30'a kadar $\mathrm{CaO}$ ve az miktarda da Fe2O3 içerdikleri görülmektedir. Külü kullanılacak aynı bitkinin farklı yöre ve iklim şartlarında yetişen örnekleriyle aynı olmadığı gözlenmektedir. Bu nedenle yapılan kül sırının verdiği etki de farklı olduğundan dolayı kül sırlarına daha da özgün sonuçlar kazandırmaktadır (Genç, 2013: 126-129).

\subsection{Kül Sırı Oluşturmada Kullanılan Hammaddeler ve Özellikler}

Elde edilen külleri içerisinde kullanmak ve doğru bir harman oluşturmak için belli hammaddelerden oluşan sır reçetesi hazırlanmıştır. Sır bünyede kullanılacak hammaddeler araştırılıp incelenerek en uygun olanları seçilip reçete oluşturulmuştur.

Üleksit (Na2O. 2CaO. 5B2O3. 11H2O): İçinde bulun- durduğu alüminyum sayesinde camlaştırıcı özelliğe sahip olan üleksit, bor bileşenli bir eriticidir. Efektli sırlar oluşturmak için sır bünyesinde kullanılmakta, kolomanitle benzer yapı bileşenlerinden oluştuklarından dolayı birbirleri yerine alternatif olarak kullanılabilirler. Sırın viskozitesini düşüren üleksitin doğadaki saf hali mermer görünümlü karnabahar şeklinde ve beyaz renk tonlarındadır (Genç, 2013:39-40).

Dolomit (CaCO3. MgCO3): Doğada aynı molekül yapisina sahip olan kalsiyum karbonat ve magnezyum karbonatın bileşiği olan dolomit bir mineral olarak büyük kayalar şeklinde bulunmaktadır. Ateşe dayanırlığından dolayı endüstride ateş tuğlası üretiminde kullanılmaktadır (Arcasoy, 1983:9-20). Sır yapımında ise erime sıcaklığı yüksek olduğundan dolayı bünyeye ergitici olarak girer ve sır çatlaklarının oluşumunu engellemekle birlikte sırın sağlam olmasında katkı sağlar (Genç, 2013:25).

Talk (3MgO.4SiO2.H2O): Sertlik derecesi düşük olan, doğada yaprak halde bulunanlara talk, kütlesel ve tanecikli dokulu olana ise sabuntaşı denilen hammaddedir. Çamur ve sır yapımında bünyeye katılan talk steatit bir maddedir (Arcasoy, 1983:20-21). Yüksek dereceli sır bünyelerde yarı yarıya bir oranda kullanıldığında ipek matı görünümü aynı zamanda katıldığı sır bünyesinde sert çizilmeye dayanaklı sır yüzeyleri oluşturmaktadır (Genç, 2013: 38).

Kaolen (Al2O3.2SiO2.2H2O): Çamur ve sır hazırlamada kullanılan kaolen özlü bir seramik hammaddesidir. $\mathrm{Bu}$ özelliğiyle diğer birçok seramik hammaddenin de temel cevheridir. Saf hali beyaz ve çıarıldı̆̆ı yöreye göre farklılık gösteren hammaddenin ergime derecesi yüksektir. Sır reçetesinde katıldı̆̆ında sırın direncini, opaklık dengesini ve viskozitesini arttırmaktadır. Sırın yüzeye sağlam tutunmasını ve hazırlanmış olan sırın çökmesini engellemektedir (Genç, 2013: 42).

Kil (Al2O3.2SiO2.2H2O): Kil, ince tane iriliğinde olup, su ile kolaylıkla yoğrulup şekil verilebilen ve uzun süre bu şekli koruyabilen steatit özsüz bir seramik hammaddesidir. Sır bünye içerisinde, sırın yüzeye sağlam tutunabilmesini, dayanıklılık ve sertlik aynı zamanda akışkanlığının kontrol altında olmasını sağlamaktadır. Sır bünyede oranı arttıkça matlaşma sağlamaktadır (Genç, 2013: 28-29).

Çinko Oksit (ZnO): Ham hali çinko olan ve yerkabuğunda en çok bulunan elementlerdendir (URL 1). Bünyesinde yüksek derecede Alüminyuma sahip olan 
çinko bu nedenden dolayı sır bünyelerde ergitici olarak kullanılmaktadır (Oyman, 2002:140). Aynı zamanda kabarcıkların oluşmasını engelleyerek sırın dirençli olmasını sağlamaktadır (Genç, 2013: 23).

\section{UYGULAMALAR}

Sır uygulamalarındaki amaç zeytin çekirdeği külünü detaylı bir şekilde incelemek, malzemenin ergitici olarak hazırlanmış sır reçeteleri içerisinde göstereceği artistik efektleri araştırıp saptamaktır. Bu amaç doğrultusunda kullanılan zeytin çekirdeği külü ile Artemis kültü ve kutsal bitkisi zeytin bütünleşmiş halde sunulmaya çalışılmıştır. Bu makalede kül sırı denemelerinden en sağlıklı uygulanabilir olduğunu tespit ettiğimiz reçetelere yer verilmiştir.

Şekil 2. Zeytinlerin fabrikada henüz işlem görmemiş halleri

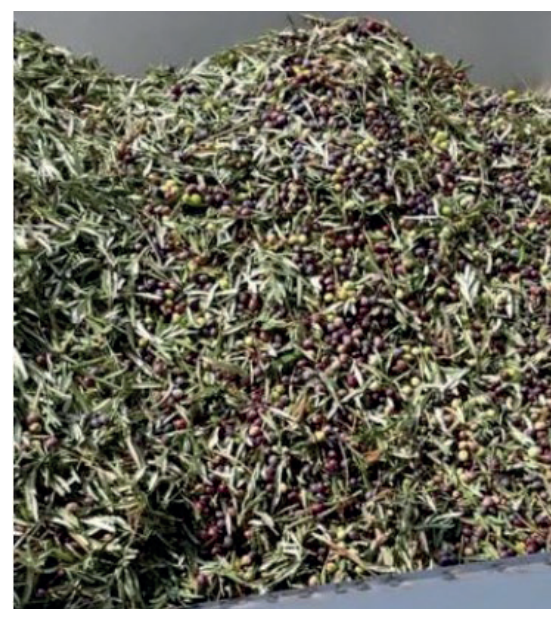

Kaynak: Ferhan Savra

Şekil 3. Zeytinlerin çekirdeklerinden ayrılması işlemi

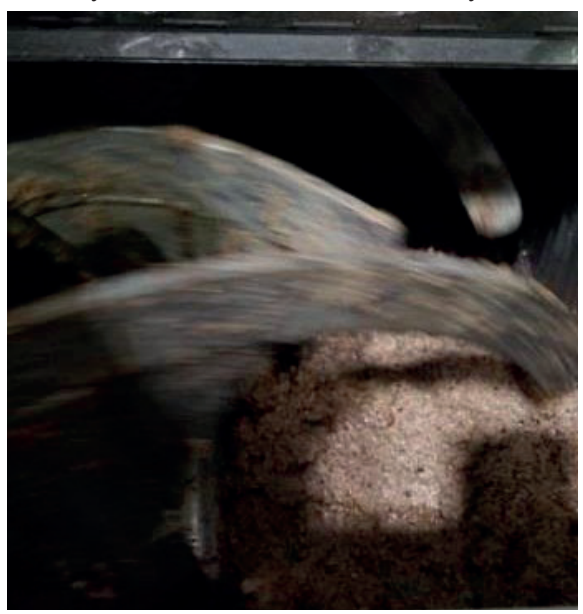

Kaynak: Ferhan Savran

\subsection{Zeytin Çekirdeğinden Kül Hazırlanması ve} Aşamaları

Zeytin çekirdekleri, günümüzde belli işlemlerden geçirildikten sonra yakacak olarak kullanılmaktadır. Bunun dışında arda kalan çekirdekler ise doğaya atık olarak karışmaktadır. Bu çalışmasında kullanılmakta olan zeytin çekirdekleri, Çanakkale'nin Geyikli ilçesinde faaliyet gösteren bir zeytinyağ 1 fabrikasından temin edilmiştir. Temin edilen zeytin çekirdekler güneş ışığında kurutulmuş, 4 saat 950 oC sıcaklıkta bütan gazlı fırında yakma işlemi uygulanmıştır. Yanma işleminden sonra \%87,53 oranında karbon kaybı yaşanmıştır.

Şekil 4. Kurutma İşlemi

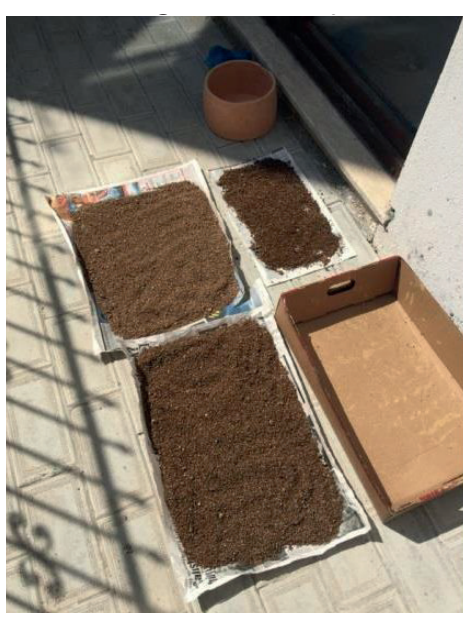

Şekil 5. Yakma İşlemi

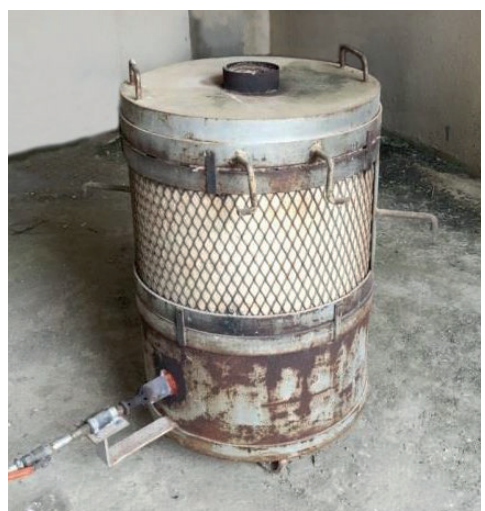

Kaynak: Yazar fotoğrafları

Yakma işlemi gerçekleştikten sonra kül haline gelen zeytin çekirdeklerinin yarısı deneme amacı ile yıkama işlemine tabi tutulmak üzere suya yatırılmıştır. Küllerin su içinde çökmesi tamamlandıktan sonra 80 mikron inceliğindeki elekle süzülmüş kurumaya bırakılmıştır. Fakat sır bünye içerisine katıldığında yıkanmış kül ile alınan sonuçlar istenilen etkiyi vermemiştir. 
Şekil 6. Elde Edilen Kül

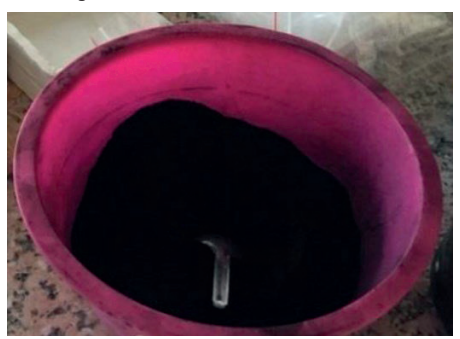

Şekil 7. Yıkama İşlemi

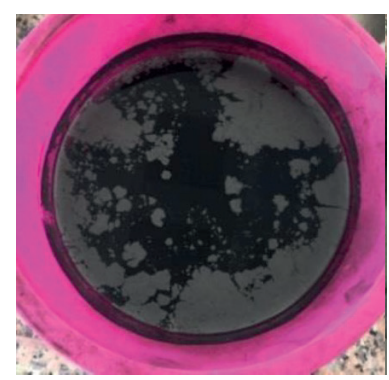

Şekil 8. Yıkanan Küllerin Süzdürülmesi

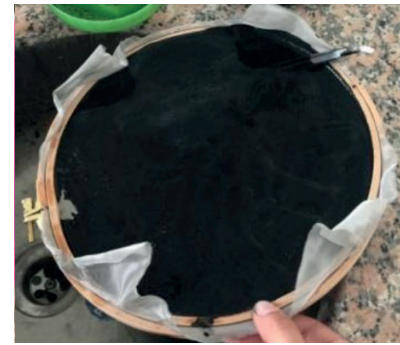

Kaynak: Yazar fotoğrafları

Elde edilen zeytin çekirdeği külleri, yıkanmış ve yıkanmamış olarak ÇOMÜ Bilim ve Teknoloji Uygulama ve Araştırma Merkezinde uygulanan XRF (X-Işını Flüoresans) analizi ile kül içerisinde bulunan bünye yapıcı ve renklendirici oksitler tespit edilmiştir. Ayrıca sonuçları yayınlanacak bir başka makalede kullanılmak üzere XRD (X-Işını Difraktometresi) testleri de gerçekleştirilmiştir. Elde edilen küller elekten geçirilerek odunla yanan ekmek fırınında iki gün kalsine edilmiştir. Isıl işleme tabi tutulan küllerle yapılan denemeler, ısıl işlem görmemiş küllerle yapılan denemelerle aynı sonuçları vermiştir. Yapılan kül sırı denemelerinin tümü ısıl işleme maruz kalmış küllerle elde edilmiştir.

Şekil 9. Isıl İşlem Görmüş Zeytin Külleri

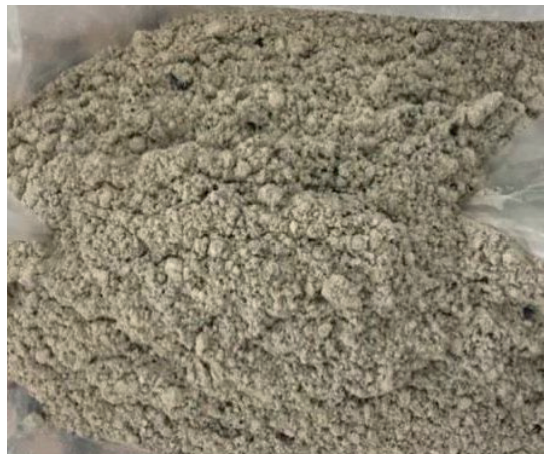

Kaynak: Yazar fotoğrafları

\subsection{Zeytin Çekirdeğinden Elde Edilen Külle Sır Denemeleri}

Öncelikle kül sırına uygun hammaddelerin araştırılması yapılmış ve seçilen hammaddelerin hangi ölçüde bünyeye katılacağı belirlenerek 100 gramlık sır reçeteleri oluşturulmuştur. Oluşturulan sir formülünün \% reçetesi tabloda verilmiştir. Sır denemelerini tümü 1040 oC sıcaklıkta, Top 40 elektrikli Nabertherm firında 7 saatte pişirilmiştir.

Oluşturulmuş olan sır reçetesi el havanında su ilaveleri eklenerek ve 15 dakika öğütülerek önceden bisküvisi yapılmış olan porselen deneme çubuklarına tek kat ince bir yüzey olacak şekilde sürülmüştür. Pişirim sonucunda (Tablo 1), yarı mat, beyaz ipeksi örtücü kül sırı elde edilmiştir.

Elde edilen sır bünyeye su ilaveleri yapılarak 15 dakika el havanında öğütülmüş porselen deneme çubuklarına iki kat ince bir yüzey olacak şekilde uygulanarak pişirilmiştir. Bünye içerisine katılan kaolen farkının yaratmış olduğu şamotlu çamur etkisi ile birlikte, mat örtücü, mermer yüzeyli bir kül sırı elde edilmiştir (Tablo 2)

Tablo 1. Deneme 1

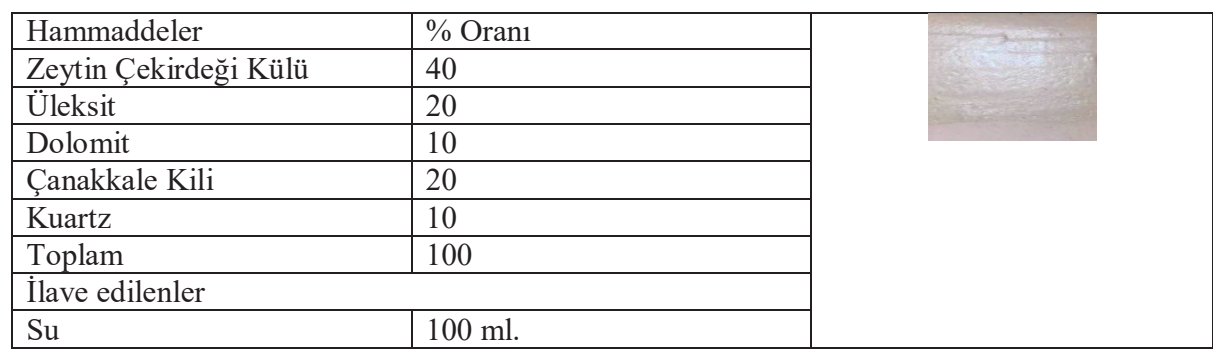

Kaynak: Yazar fotoğrafları 
Tablo 2. Deneme 2

\begin{tabular}{|c|c|c|}
\hline Hammaddeler & $\%$ Oran 1 & \\
\hline Zeytin Çekirdeği Külü & 20 & \\
\hline Üleksit & 30 & 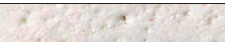 \\
\hline Dolomit & 10 & +3 \\
\hline Kaolen & 20 & 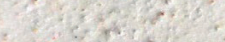 \\
\hline Talk & 10 & $x^{3}=$ \\
\hline Kil & 4 & 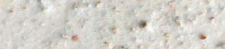 \\
\hline Boraks & 16 & \\
\hline Toplam & 100 & 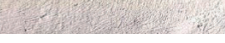 \\
\hline \multicolumn{2}{|l|}{ İlave edilenler } & \\
\hline $\mathrm{Su}$ & $100 \mathrm{ml}$. & \\
\hline
\end{tabular}

Kaynak: Yazar fotoğrafları

Tablo 3. Deneme 3

\begin{tabular}{|l|l|}
\hline Hammaddeler & $\%$ Oranı \\
\hline Zeytin Çekirdeği Külü & 20 \\
\hline Üleksit & 30 \\
\hline Dolomit & 10 \\
\hline Çanakkale Kaoleni & 20 \\
\hline Talk & 10 \\
\hline Kuartz & 10 \\
\hline Toplam & 100 \\
\hline İlave edilenler & $100 \mathrm{ml}$. \\
\hline Su &
\end{tabular}

Kaynak: Yazar fotoğrafları

İlaveleri yapılan sır reçetesi, 15 dakika el havanında öğütüldükten sonra iki kat ince olacak şekilde deneme çubuklarına uygulanmış ve pişirilmiştir. Oluşturulan bu reçete ise Deneme 2 ile (Tablo 2) aynı olup sadece bünye içerisine giren kaolen farkından dolayı kül sırı hem istenilen sonucu vermiş hem de parlak ve hafif krakle çatlakları olan bir görünüme bürünmüştür (Tablo 3$)$.

Uygulanan sır reçeteleri üzerinde renklendirici oksit denemeleri de yapılmıştır. Deneme 1'de (Tablo 1) verilen \% sir reçetesine ek olarak 0,5, 1, 2, 3'er gr. olmak üzere demir (Fe2O3), mangan (MnO3), krom (CrO2), bakır (CuO2) oksit eklenmiş ve 1040 oC sıcaklıkta 7 saat elektrikli fırında pişirilerek renkli denemeler gerçekleştirilmiştir.

Şekil 10. Soldan sağa doğru 0.5, 1, 2, 3 gr. demir oksit katkılı renk denemeleri
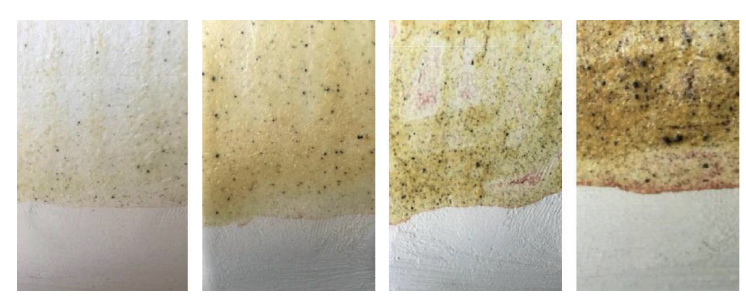

Kaynak: Yazar
Demir oksit kullanılan denemelerde gösterildiği gibi, sarı ve tonlarını veren örtücü sır elde edilmiştir. İstenilen renge 0,5 gr. demir oksit eklenen denemede ulaşılmıştır.

Şekil 11. Soldan sağa doğru 0.5, 1, 2, 3 gr. mangan oksit katkılı renk denemeleri
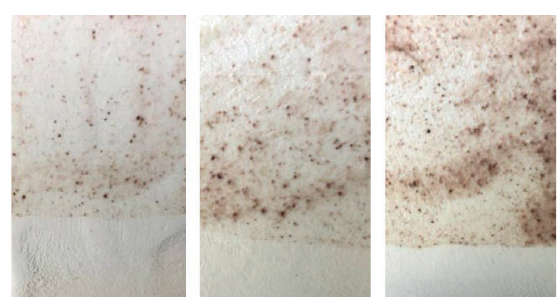

Kaynak: Yazar

Sır reçetesinde kullanılan mangan oksit pişirim sonucunda örtücü, kahverengi ve tonlarını vermiştir. Dört denemenin her birinde istenilen sonucu vermiştir.

Şekil 12. Soldan sağa doğru 0.5, 1, 2, 3 gr. krom oksit katkılı renk denemeleri
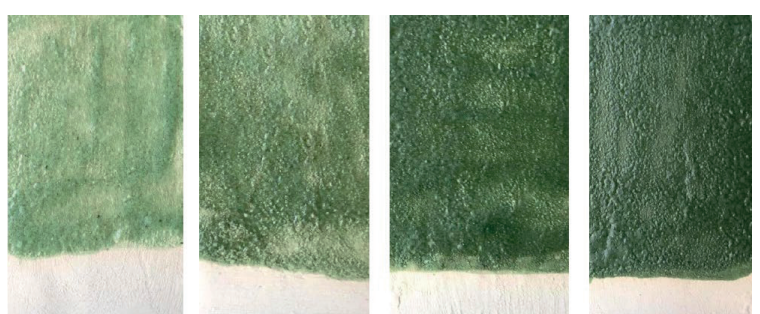

Kaynak: Yazar 
Krom oksitli sır denemelerinde örtücü, yeşil ve tonları elde edilmiştir. İstenilen sonuç 2 ve $3 \mathrm{gr}$. krom oksit katkılı denemede yakalanmıştır.

Şekil 13. Soldan sağa doğru 0.5, 1, 2, 3 gr. bakır oksit katkılı renk denemeleri
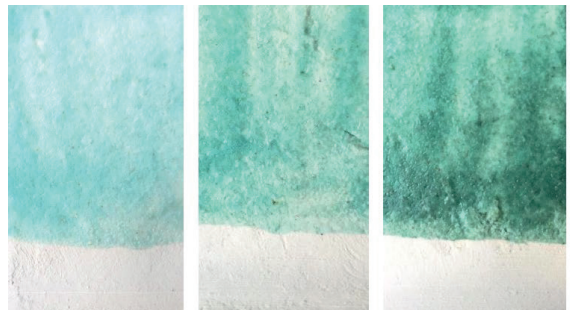

Kaynak: Yazar

Sır reçetesinde kullanılan bakır oksit ile yeşil, türkuaz ve tonları yakalanmıştır. Pişirim sonucunda sır örtücü ve denemelerin her birinde istenilenden sonuç elde edilmiştir.

Yapılan testler sonucunda zeytin küllerinde eser mik- tarlarda saptanmış olan P2O5, SO3, Cl, Ga, Ge, As2O3, $\mathrm{Rb} 2 \mathrm{O}, \mathrm{Y}, \mathrm{Nb} 2 \mathrm{O} 5, \mathrm{Pd}, \mathrm{In}, \mathrm{Te}, \mathrm{I}, \mathrm{Cs}, \mathrm{La}, \mathrm{Pr}, \mathrm{Hg}, \mathrm{Tl}, \mathrm{Th}$, kimyasalları ise ise makalede tablolanmamıştır.

\subsection{Tasarımlar ve Uygulamalar}

Tasarımlarda, Artemis'in kült heykelindeki yumurta dizileri meme olarak düşünülmüş ve tek bir formun birim olarak bir araya gelerek bütünlük oluşturacağ heykel çalışmaları tasarlanmıştır. Form alçı tornasında şekillendirilip, iki parçalı kalıbı alınmıştır. Birim tekrarı ana tasarım unsuru olarak kullanılmıştır. Tasarımlar Artemis'in birbirinden ayrılmayan üç karakteristik özelliğinden esinlenerek ortaya çıkmıştır. Bu üç karakteristik özellik heykellerin temelini oluşturmakla beraber birbirinden ayrılmaz bir bütün olarak düşünülerek evreleri atladıkça metamorfoza uğramışlardır. Ezoterik anlamda üç sayısı, üçgen olarak kabul görülüp fikir ile bağdaştırılmaktadır.

Tablo 4. XRD analiz sonuçlarına göre Zeytin Çekirdeği Külünde Bulunan Bünye Yapıcı Hammaddeler

\begin{tabular}{|l|l|l|}
\hline Bünye Yapıc1lar & Yıkanmış Küllerde & Yıkanmamış Küllerde \\
\hline $\mathrm{MgO}$ & $<0,75$ & $<0,73$ \\
\hline $\mathrm{Al}_{2} \mathrm{O}_{3}$ & $<0,80$ & $<0,066$ \\
\hline $\mathrm{SiO}_{2}$ & $<0,023$ & 0,027 \\
\hline $\mathrm{K}_{2} \mathrm{O}$ & 0,38 & 0,88 \\
\hline $\mathrm{CaO}$ & 0,43 & 0,40 \\
\hline $\mathrm{ZnO}$ & $<0,0006$ & $<0,0006$ \\
\hline $\mathrm{Br}$ & $<0,0005$ & $<0,0005$ \\
\hline $\mathrm{SrO}$ & 0,0007 & 0,0009 \\
\hline $\mathrm{ZrO}$ & $<0,0007$ & $<0,0007$ \\
\hline $\mathrm{BaO}$ & $<0,010$ & $<0,009$ \\
\hline $\mathrm{PbO}$ & $<0,0006$ & $<0,0006$ \\
\hline $\mathrm{Bi}$ & $<0,0005$ & $<0,0005$ \\
\hline
\end{tabular}

Kaynak: Yazar

Tablo 5. XRD analiz sonuçlarına göre Zeytin Çekirdeği Külünde Bulunan Renklendirici Oksitler

\begin{tabular}{|l|l|l|}
\hline Oksitler & Y kanmiş Küller & Y1kanmamış Küller \\
\hline $\mathrm{TiO}_{2}$ & $<0,009$ & $<0,009$ \\
\hline $\mathrm{V}_{2} \mathrm{O}_{5}$ & $<0,003$ & $<0,003$ \\
\hline $\mathrm{Cr}_{2} \mathrm{O}_{3}$ & $<0,010$ & $<0,015$ \\
\hline $\mathrm{MnO}$ & 0,003 & 0,004 \\
\hline $\mathrm{Fe}_{2} \mathrm{O}_{3}$ & 0,034 & 0,050 \\
\hline $\mathrm{CoO}$ & $<0,0006$ & $<0,0006$ \\
\hline $\mathrm{NiO}$ & $<0,0006$ & $<0,0006$ \\
\hline $\mathrm{CuO}$ & 0,014 & 0,012 \\
\hline $\mathrm{Se}$ & $<0,0005$ & $<0,0005$ \\
\hline $\mathrm{MoO}$ & $<0,0007$ & $<0,0007$ \\
\hline $\mathrm{Ag}$ & 0,004 & 0,005 \\
\hline $\mathrm{CdO}_{2}$ & 0,002 & 0,003 \\
\hline $\mathrm{SnO}_{2}$ & $<0,001$ & $<0,001$ \\
\hline $\mathrm{Sb}_{2} \mathrm{O}_{3}$ & $<0,002$ & $<0,002$ \\
\hline $\mathrm{CeO}_{2}$ & $<0,005$ & $<0,004$ \\
\hline $\mathrm{WO}_{3}$ & $<0,0006$ & $<0,0006$ \\
\hline $\mathrm{Au}$ & $<0,0005$ & $<0,0005$ \\
\hline
\end{tabular}

Kaynak: Yazar 
Şekil 14. Heykel düzenleme, 5. Metamorfoz evresi, $50 \times 50 \times 3$ cm., Bu çalışmada şekil 13 de yer alan $3 g r$. bakır oksit katkılı kül sırı bünye ve yer yer altın yaldız kullanılmıştır.

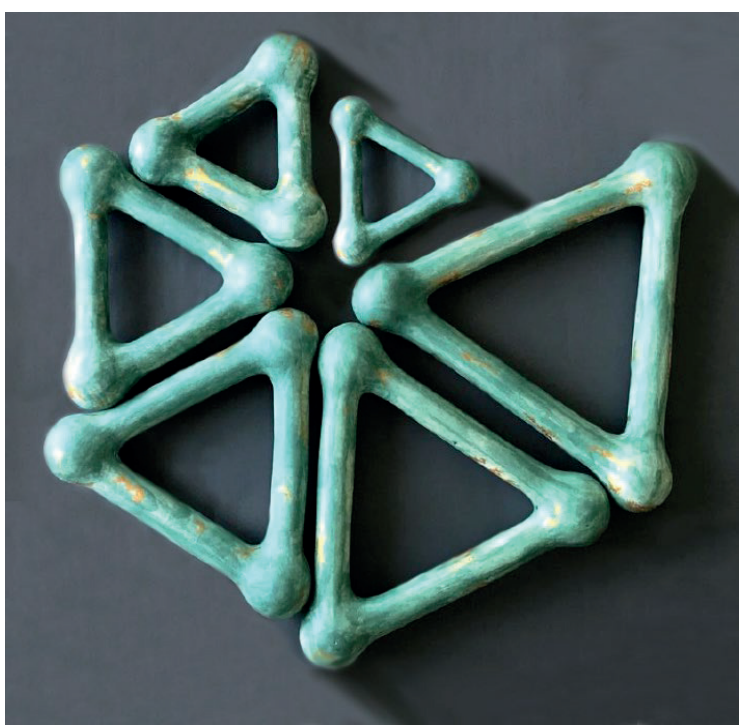

Fotoğraf: yazar arşivi

Üç sayısı birbiri ile kesiştiğinde nötrleşerek form değiştiren iki farklı enerjiyi sembolize etmektedir. Bu iki enerjiden biri etkin olan yaratıcılık diğeri ise edilgen olan doğurganlık birbiri ile karşılaştığında ortaya farklı ve yeni fikirlerin çıkmasına neden olmuştur. Bu nedenle tasarımlar kadını simgeleyen kutsal üçgenin ezoterik açıdan anlamını da barındırmaktadır. Heykeller dokuz parçadan oluşmaktadır. Bunun nedeni ise üç sayısının üç katı olduğundandır. Aynı zamanda heykellerde tercih edilen renkli sırlar toprak ve toprak renkleri ve zeytin ağacını temsil eden yeşil ve yeşilin tonlarıdır.

Şekil 15. Heykel, 5. Metamorfoz evresi, 35 x 40 cm., Bu çalışmada şekil 12 de yer alan 3gr. krom oksit katkılı

kül sırı bünye kullanılmıştır.

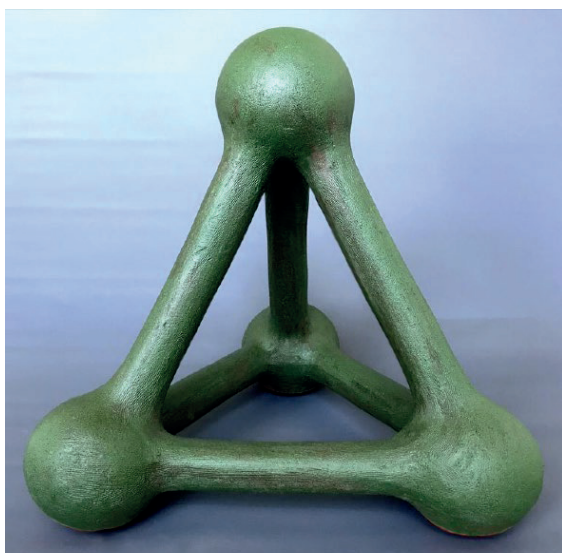

Fotoğraflar: yazar arşivi

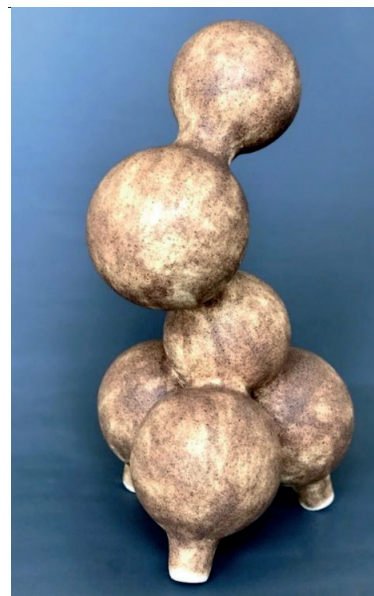

Şekil 16. Heykel,

Metamorfoz 1/2/4, 23 x $43 \mathrm{~cm}$., Bu çalışmada şekil 11 de yer alan 3gr. mangan oksit katkılı kül sırı bünye kullanılmıştır.

\section{SONUÇ}

$\mathrm{Bu}$ araştırmada, hazırlanan zeytin çekirdeği küllerinin, analiz sonuçlarından (Tablo 4) elde edilen verilere göre ağırlıklı olarak potasyum ve kalsiyum içerdiği tespit edilmiştir. Bu hammaddelerin kül sırlarının oluşumunda olumlu etkileri bulunduğu yapılan sır testleri saptanmıştır. Kullanılan külün yıkanmış ve yıkanmamış olarak XRF testleri gerçekleştirilmiş, bu sayede reçetedeki etkin maddelerin neler olduğu net ve bilimsel bir biçimde ortaya konmuştur. Sonuçları sunulan zeytin çekirdeğinden üretilmiş özgün kül sırlarına, istenilen sonuç elde edilene kadar bünyeyi oluşturan hammadde oranlarında küçük değişiklikler yaparak ulaşılmıştır. Ayrıca zeytin çekirdeğinden üretilen ve önerilen yedi farklı kül sırının, yerel değerlerle bütünleșen heykel çalışmalarında uygulanmasıyla, anlam bütünlüğünü sağlanmaya çalışılmıştır.

Saptanan reçeteler beyaz ve porselen çamurdan üretilen bisküvi pişirimi gerçekleşmiş deneme çubuklarına uygulanarak elektrikli fırında 7 saat 1040 oC sıcaklıkta pişirilmiştir. İstenilen sonucu veren üç farklı reçetede, parlak, mat ve ipek matı örtücü kül sırları elde edilmiştir. İpek matı elde edilen reçeteye ek olarak demir, mangan, bakır ve krom oksit eklenerek renklendirilmiştir. Elde edilen kül sırlarının bekleme süresi içerisinde su kaybının az olduğu ve partiküler çökmesinin olmamasından dolayı kullanım rahatlığı sağladığı gözlemlenmiştir. Aynı zamanda XRF testlerinin analizleri doğrultusunda zehirsiz, sağlıklı yapıda bir sır bünye olduğu saptanmıştır.

Renkli sır denemelerinin, beyaz çamurdan üretilen ve bisküvisi yapılmış deneme çubuklarının yüzeylerine ince uygulanmasından dolayı sır pişiriminden sonra 
dalgalanmalar oluştuğu görülmüştür. Bu durum sir denemesinin istenilen sonucu vermesine engel olmamıştır. Heykel tasarımlarının tamamının içi boşaltılmış ve kurumalarının ardından bisküvi pişirimleri, elektrikli fırında 6 saat ve 1000 oC sıcaklıkta gerçekleştirilmiştir. Bisküvi fırınına giren heykellerin pişiriminden sonra ek yerlerinde ayrılma, bükülme, çökme ve deformasyon, sırlı pişirimde ise akma ve yapışma gözlemlenmemiştir. Sonuç olarak hem sanatsal hem de bilimsel yöntemlerin bir arada kullanılmasıyla, zeytin çekirdeğinden elde edilen kül sırlarının olumlu etkiler ortaya çıkarttığ 1 ve kül sırlarında alternatif hammadde olarak kullanılabilirliği saptanmıştır.

\section{KAYNAKÇA}

ALKAN, D. (1998), Çam Ağacı, Ceviz Kabuğu ve Soya Fasulyesi Küllerinin 1200 oC'de Sır Hammaddesi Olarak Değerlendirilmesi, Anadolu Üniversitesi Sosyal Bilimler Enstitüsü (Yayımlanmamış Yüksek Lisans Tezi)

ATEŞ, Ö, Ş. (2012). Yakındoğu Demirçağ Uygarlıklarında Hayat Ağacı Ínancı", (Yayımlanmamış Yüksek Lisans Tezi) Dicle Üniversitesi, Sosyal Bilimler Enstitüsü, Diyarbakır.

COOK, J. M. (1973). The Troad: An Archaeological and Topographical Study, Oxford

ERTAN, İ., ve BAKIR, G. (2018), "Klazomenai Zeytin İşçiliği, Zeytinin Akdeniz'deki Yolcuğu" Konferans Bildiriler, Dinç Ofset Yayınları: İzmi

GENÇ, S. (2013) Artistik Seramik Strları Sır Sanatı, Boyut Matbaacılık A.Ş., İstanbul

GÖKÇE, M., KURT, S. (2020), Ağaç Kültü Örneğinde Muğla ve Civarında Eski İnanışlar, Yörük Araştırmaları-I Sempozyumu Bildiriler kitabı, Konya, 148

GÖMEÇ, S (2003) Eski Türk inancı Üzerine Bir Özet, Ankara Üniversites Dil ve Tarih-Coğrafya Fakültesi Tarih Bölümü Tarih Araştırmaları Dergisi, $33 / 21$

GÜNEŞ, P,Ç. (2014), $1280^{\circ} \mathrm{C}^{\prime}$ de Gelişen Odun Külü Katkılı Sır Araştırmaları Ve Uygulamalar Dokuz Eylül Üniversitesi Güzel Sanatlar Enstitüsü Seramik Ve Cam Tasarımı Anasanat Dalı (Yayımlanmamış Sanatta Yeterlik Tezi)

HEPOĞLU, E. ve İNCE, H. Ç. (2019). Mitolojik Ağaçlar Ağaç Ve Bitki Türleri Kuş Türleri. https:/ / docplayer.biz.tr/57489972-Mitolojik-agaclar-agac-ve-bitki-turleri-kusturleri.html (Erişim tarihi: 27.06.2021).

ILGAR, R (2016), Çanakkale İlinde Zeytin Yetiştiriciliği ve Yaşanan Sorunlar, İstanbul Üniversitesi Edebiyat Fakültesi Coğrafya Dergisi, No:32, 19 KUBAT, L. (2020), Kestane Kabuğu Külünün Sır Bileşeni Olarak Kullanılabilirliğinin Araştırılması Akademik Sanat, Cilt 5, Sayı 9

NAHYA, N. (2011), Zeytin: Tüm Ağaçların İlki, İlahların ve İnsanların Onuru, Metro Gastro: İstanbul. s. (88-90)

OYMAN, R.E (2002) Uygulamalı Seramik Teknolojisi Cilt I, (Çev. İlker Özkan), Sacmi İstanbul, Via Selice Provinciale 17/A-40026 İmola (BO) İtalya

ROGERS, P. (2003), Ash Glazes, University of Pennsylvania Press

SARNIÇ, K. Ö., KUBAT, L. (2007), Eskişehir Bölgesi Şeker Pancarı Küspesi Küllerinin Sır Bileșeni ve Renklendirici Olarak Kullanılabilirliğinin Araştırılması SERES'07 Bildiriler kitabı
SERDAROĞLU, Ü. ile röportaj (Assos Kazıevi, Çanakkale, 16 Temmuz 1994)

STRABON (Çev.PEKMAN, A), Geographika, Antik Anadolu Coğrafyası, XII-XIV, Arkeoloji ve Sanat Yayinlarl, 2000, İstanbul

ŞÖLENAY,E., TURAN, N. (2020), Patates Kabuğu Atığı Küllerinin 1160 ${ }^{\circ} C^{\prime}$ de Sır Hammaddesi Olarak Değerlendirilmesi", Inonu University Journal of Art and Design, 61-70

TIZGÖL, K., DEMIR, Ö,G. (2016), Bir Sera Atığı Olarak Patlıcan Dalı Külünün Düşük Dereceli Seramik Sırlarında Kullanımı" Akdeniz Sanat Dergisi, Cilt 9, Sayı 18

ÜNAL, S., AKGEYİK, E. (2020) Gül Posası Külünün Seramik Yüzeylerde Kullanımı" Akademik Sanat, Cilt 5 Sayı 10

URL1 https://yeryuzuagaci.wordpress.com/2016/09/27/anadolu-kulturunde-zeytin-agaci/ (Erişim Tarihi 03.04.2018).

URL2http: / / www.wikizeroo.net/index.php?q=aHR0cHM6Ly90ci53aWtpcGVkaWEub3JnL3dpa2kvw4dpbmtv (Erişim Tarihi 19.12.2018).

\section{TEŞEKKÜR}

Bu makalenin hazırlanmasında YL-2017-1322 numaralı proje ile destek olan Çanakkale Onsekiz Mart Üniversitesi Bilimsel Araştırma Projeleri Koordinasyon Birimine, zeytin çekirdeklerinin temininde destek olan Doç.Dr. Ferhan Savran'a teşekkür ederiz.

Bu Makale Çanakkale Onsekiz Mart Üniversitesi Bilimsel Araştırma Projeleri Koordinasyon Birimi tarafından SYL2017-1322 numaralı proje ile desteklenmiştir. 